\title{
From Inner Peace to World Peace: Jagannath Consciousness in the Literature of Odisha
}

\author{
Guruprasad Mohapatra' \& Swati Samantaray ${ }^{2}$ \\ ${ }^{1}$ Research Scholar, School of Humanities, KIIT University, Bhubaneswar. orcid.org/oooo- \\ ooo3-1736-3564. Email: gprasadkhurda@gmail.com \\ ${ }^{2}$ Associate Professor, School of Humanities, KIIT University, Bhubaneswar. \\ orcid.org/oooo-0oo2-4823-9278. Email: swati.sray@gmail.com
}

Received October 30, 2017; Revised December 15, 2017; Accepted November 30, 2017; Published December 25, 2017.

\begin{abstract}
Lord Jagannath of Puri is considered to be the focal point of the cultural synthesis of Odisha. This is manifested in innumerable sacred scriptures and in ritualistic practices of the revered divinity - Lord Jagannath. This paper shows how the literature of Odisha presents Jagannath consciousness as a way to achieving world peace from inner peace of mind. Jagannath consciousness follows humanism and it preaches the philosophy of love and peaceful co-existence among the entire human community. Moreover, it proclaims the victory of human endeavour over all narrowness and establishes universal brotherhood. The prime objective of Jagannath culture is to inspire the worshipper as well as the devotees to transcend the barriers of individual identity to achieve cosmic consciousness. It is believed that this state of cosmic consciousness is attained through the realization of soul, and it brings glory to life and enhances epistemological vision of humankind. The paper studies the vast literary and artistic traditions of Odisha in order to show how the principles of synthesis, assimilation and progression are inherent in the Jagannath culture.
\end{abstract}

Keywords: Jagannath Consciousness, Jagannath Cult, Vaishnavism, Jainism, Buddhism, world peace.

\section{Introduction}

The legend of Lord Jagannath has been inextricably interlinked with the historicity of Odisha, socio-cultural coalescence and religio-traditional values since the time immemorial. The reverential worship of Lord Jagannath, the social flavour and the ethnic values associated along with, constitute the quintessence of the cult of Jagannath. Religion, in Indian philosophy, is appraised to be an appropriate attempt to encounter with the Ultimate Reality. The approach of metaphysical enquiry reveals the Reality in its totality with the understanding of 'Self' - where both the individual identity and the transcendental identity have a contextual uniqueness. Although the intrinsic value of an individual is different from that of cosmic value, it is believed that at a wider spectrum they merge with each other. This concept is best exemplified in the cult of Jagannath which has a sublime sense of compositeness.

(c) AesthetixMS 2016. This Open Access article is published under a Creative Commons Attribution Non-Commercial 4.0 International License (http://creativecommons.org/licenses/by-nc/4.0/), which permits non-commercial re-use, distribution, and reproduction in any medium, provided the original work is properly cited. For citation use the DOI. For commercial re-use, please contact editor@rupkatha.com. 


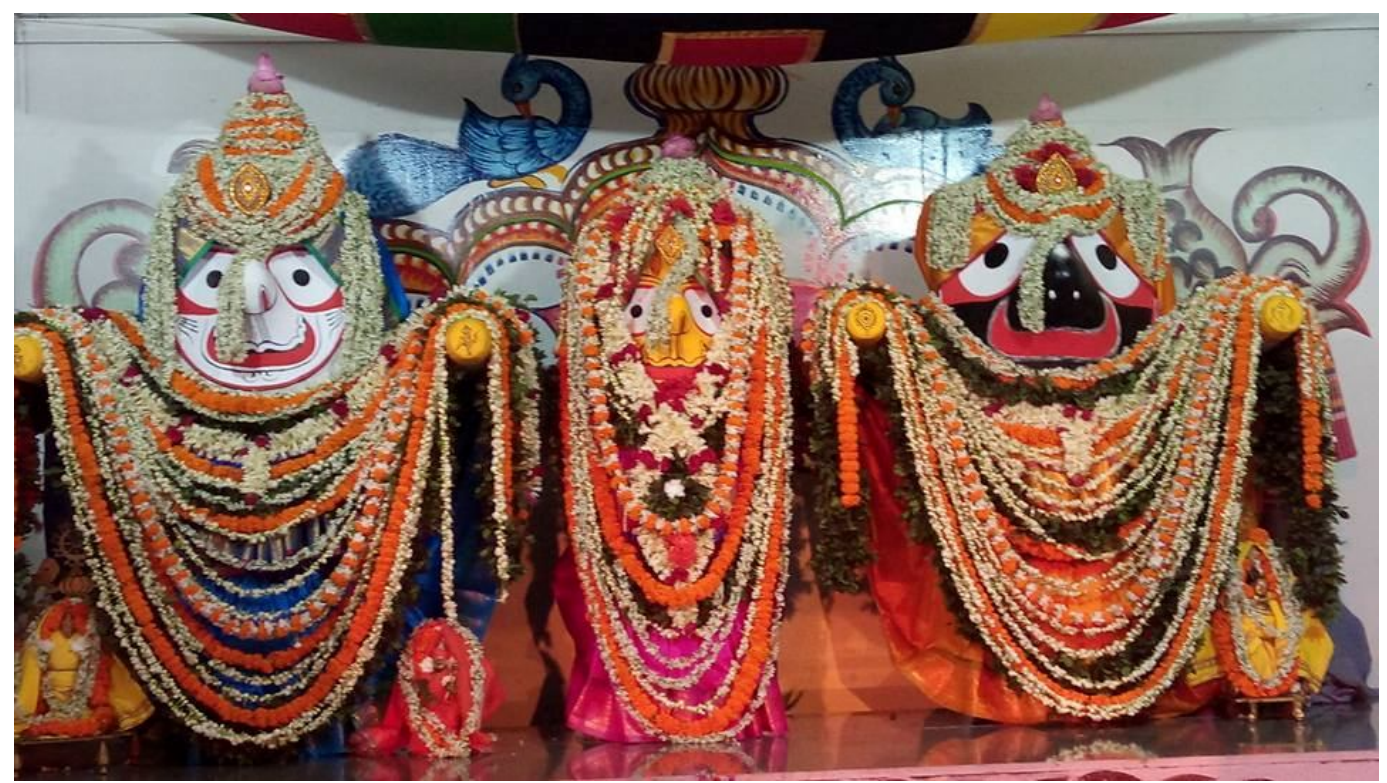

Image 1: Lord Jagannath, Devi Shubhadra and Lord Balabhadra. Photo taken by Dr. Samantaray.

\section{Jagannath Consciousness and the Literature of Odisha}

Although people in Odisha pay homage to different Gods or Goddesses, Lord Jagannath has gained universal reverence for the reflection of cosmopolitanism in His rituals and celebrations. On the one side, as the state deity of Odisha, Lord Jagannath has been the inspiring and encouraging Divine force behind the religious, cultural, spiritual as well as socio-political life of odia people. 'Mahaprasad' (the holy food of the Lord) is considered as an inimitable contribution for social unity regardless of caste stigma of Hindu society. Existence of a number of mathas (ashrams) around the temple established by some of the great preachers of India suggests that the Lord embraces all - whether oriental or occidental, whether rich or poor. On the other side, He propagates a spiritual vision against materialism, principle of universal brotherhood while putting distinct emphasis on Cosmic Consciousness - the blissful experience when the individual mind becomes one with the cosmic mind or the Over Soul. Jagannath consciousness is reflected in patta chitra painting, palm-leaf etching, architecture, sculpture, folklore, dance forms, music, celebrations and uniqueness in dress material too. The Lord has been a beacon of inspiration highlighting the principles of synthesis, integration and accommodation since centuries together. In spite of presidential political changes and social evolutions the unique essence of Jagannath culture has sustained intact.

Lord Jagannath is perceived not only as mysterious but also enigmatic with regards to His antiquarian prospect. His origin is undated, His culture is claimed to be eternal. He is revered as the saviour from earthly melancholia in the shadow of mysticism and eulogized on the canvas of devotion. The concept of Jagannath culture as a living philosophy has been explained by Debi Prasanna Rath as follows:

"Though the culture is woven around the deity Jagannath, it primarily represents a lifeview which merges within itself differing and even contrasting religious view-points. Hence, universal brotherhood, democracy, anti-communalism, anti-racialism and religious tolerance are bedrocks of this culture."(Rath, Preface ii) 
The compendium of ancient writings has accepted Lord Jagannath as a symbol of Absolutism. One of the earliest works related to Jagannath consciousness is the Mahabharat of Sarala Dasa, written in the 15th century. Sarala Dasa appears to ascribe Madhava as the initial form of Jagannath, worshipped by Visvabasu (tribal chief of Nilagiri). During the 16th century Sri Chaitanya (the pioneer of Vaishnavism in India) portrayed Lord Jagannath as Krishna. Under his influence the poets like Jagannath Dasa, Achyutananda Das, Ananta Das started presenting Lord Jagannath in the same way. The poetic work Deula Tola of Nilambara Das provides an account of the Trinity in the Grand Temple at Puri. Jagannath Dasa (an Odia poet) presents the events behind the construction of the Grand Temple and the images in his work Daru Brahma Gita. Salabega was one of the great poets of 17 th century Odisha. Reviewing his poetic creations we discover a deep devotional approach of the poet towards the Lord. Subsequently the poets such as Dinakrushna Dash, Saria Vika, Baidyanath Dwija, Biprakantha Dash have tried to establish Jagannath as the saviour of mankind from all the mundane melancholia. 18th century is said to be the golden period for the growth of Odia literature. Moreover, the poets like Upendra Bhanja, Banamali Dash, Nityananda Dash, Biswanath Khuntia and many others have authenticated the importance of Lord Jagannath in both personal life of an individual and social life of the Odias. The poets of the 19th century - Jadumani Mohapatra, Chandan Hajuri, Gaurachandra Narapati and Hadi Dasa - have been more intimate to the Lord. The consciousness of the Lord reached the apex on the poetic canvas in comparison to the prose pieces. The modern Odia poets like Jayanta Mohapatra, Bibhu Padhi, Vagaban Jaysingh and Subhendu Munda have been more versatile to depict the symbolic values associated with Jagannath cult.

The accounts of research projects on Lord Jagannath go back to the early nineteenth century when the cult was appreciated by orientalists like A. Cunningham and W.W. Hunter. They worked on the historicity of the worship of the Lord and alleged it having Buddhist origins. O' Mally's Puri Gazetter (1929) lays stress on the Buddhist background of Lord Jagannath primarily in connection with the tribal origin and subsequent gain of presidential reverence as the National Deity of the Odias. In the latter part of nineteenth and early twentieth century Jagannath emerged as the symbol of the Odia movement and was praised by the great poets of Odisha, and the research was regulated primarily by Bengali historians like R. L. Mitra (1824 1891), M.M. Ganguli (1844-1898), R.D. Banerji (1885-1930) and by the 1940s, R.C. Majumdar (1888$1980)$ and D.C. Sircar (1907-1984) joined hands to trace the origin of the cult, keeping the view on two important factors like general history and ethnology.

A new horizon of investigation on Jagannath cult was inaugurated in the name of 'Orissa Research Project' by the South Asia Institute in Heidelberg between 1969 and 1977. It's publications became packs and parcels to the study during the mid 1980s. These publications helped a group of German and Indian scholars like Stietencron, Hermann Kulke, Burkhard Schnepel, G.C. Tripathi and G.N. Dash to go ahead with full force stimulating diversification of research foci and methods. Stietencron's praiseworthy endeavour to organize the spatial separation of sacred centers and shrines, Kulke's attempt to look into legitimation of regional kingdoms on the basis of social history, Schnepel's study of tribal kings and village level cultural performance, Handeberg's structural interpretation of Jagannath cult, Frederique A. Marglin's books on the Devadasis of Puri opened a promising field for studies. The studies on the analysis of contemporary influences on the constructions of the past, by G.N. Dash, the translation of the Sanskrit version of 'Puri Chronicle' and 'Communication with God' by G.C. Tripathi are valuable steps in this dimension. They modified the concept of Puri from 'Sacred Complex' to 'Cultural Complex'. They focused on the process of cultural changes and secularization under the umbrella of Jagannath cult. 
Reviewing the literary labyrinth with reference to the study of Jagannath cult, we come across significant events which eventually elated an era to enhance Jagannath studies in Odisha. In 1969, two scholastic souvenirs were brought out on the eve of the foundation stone-lying ceremony of the Jagannath Temple in Delhi. Odia scholars like S.N. Rajaguru, K.N. Mohapatra, K.C. Mishra and others contributed their articles which constituted an anthology of brief research papers on Jagannath. The publication made the pavement for 'The Oriya School of Jagannath Studies'. They were the theory oriented scholars, to systematize religious, historical, architectural and literary themes, connected with the cult. In 1971, the Ph.D. thesis of K.C. Mishra entitled 'The Cult of Jagannath' was published as the first scholarly monograph on the Lord and the study sheds light on the socio-historical origin of the Jagannath Cult in connection with different tribes, dynastic and spiritual movements in early and medieval Odisha. Subsequently, the private and government sponsored research institutes like Sri Jagannath Sanskrit Viswavidyalaya, Sri Jagannath Research Centre at Puri, Sri Jagannath Research Centre at Bhubaneswar reinforced the go. The souvenir volumes, periodicals and proceedings of the above mentioned organizations became the beacon for researchers of new-generation and medium to popularize the cult.

The origin and antiquity of Lord Jagannath has been a query to most of the scholars like B.M. Padhi, S.N. Rajguru, K.S. Behera, Brij Kishore Ghosh, Surya Narayan Dash, Yaspal Jain, W.H. Lee, Surendra Mohanty, Kedaranath Mohapatra and Mayadhara Manasingh. They have made vehement effort to trace the root of Jagannath among the sabara tribes of Mahendragiri mountainous region in South-Odisha. K.C. Mishra and A. Eschmann came forth with peculiar evidence of similarities between the Jagannath cult and the spiritual practices of Kandhas (adivasi tribes) in Dhenkanal district of Odisha. An eminent archaeologist Jitendra P. Sing Deo claims Western Odisha to be the origin of Jagannath worship. The works of the above said predecessors are seminal historiographical studies. The studies on Kanchi Kaberi, Deula Tola, Daita and Suddha Saura of Puri by G.N. Dash, critical analysis of epigraphical and literary sources on the history of the cult of Jagannath by Kailash Chandra Dash, are based on illustrated analysis of manuscripts connected with Lord Jagannath. Nilakantha Das (1884-1969), an eminent literary architect of Odisha, identifies the Kalinga Jaina with earlier form of Jagannath. Kedarnath Mohapatra, a notable archaeologist and scholar of palm leaf manuscript, thinks that Puri was a famous religious centre of the Jainas. S.K. Chatterjee (1890-1977) attributed this specifically to a kind of 'Protestant Hinduism' inspired by Buddhism. The German scholar Stietencorn, has traced the origin of Sri Jagannath with Saivism. Professor P. K. Mukherjee has discussed the glory of the Car Festival during the British period, in his book 'Car Festival under East India Company in Bharat' (1969), Gauri Sankar Bhattacharya has tried to highlight the social significance of the grand celebration in his 'The Jagannath Car Festival at Puri in March of India' (1956). A critical study of the scholastic literary works reveals the fact that most of the projects are done on the understanding of Indian mind and evolution of Jagannath consciousness and cult, rising from primitive deity to state deity. This research paper may be considered as a modest attempt to ordain the cosmic impact of Jagannath culture upon society and how world peace may be achieved from inner peace of mind.

\section{Jagannath Consciousness as a Medium of World Peace}

The flow of different spiritual currents in India have provided a stable foundation for this culture in the periodic process of congregation in one and unique philosophic concept. Lord Jagannath embodies in Himself the quintessence of some of the remarkable world religions. The fundamental values of most faiths have been inter-woven intricately with intelligent compromises in a such deafening democratic manner that Lord Jagannath proves Himself to be an epitome of 
heterogeneity and synthesis. The issue of consciousness has been proved to be a significant challenge for inquisitive human intellect since centuries.

"The relation between the Absolute, infinite, self-existent and immutable and the finite human individual who is enmeshed in the temporal order is unimaginably intimate though difficult to define and explain" (Samantaray 50).

In this connection we may say that consciousness has various implications ranging from one's cognition to his recognition as a spark of cosmic consciousness. The cult of Lord Jagannath is the rendezvous of religion with philosophy. Jagat (cosmos) is the Flux. Jagannath (Jagat + nath) is revered to be the Lord of this flux inhabiting and presiding over it. Hence, He is the symbol of divine dynamism. Jagannath consciousness constitutes an eclectic stream of thoughts, assimilating and incorporating ingenious cultic influences in order to emerge itself as an exceptional convergence of diverging religiosities.

"Consciousness has different connotations ranging from awareness of one's perception to feelings and recognition of oneself as an agent endowed with purpose and free will. It is the very basis of all forms of knowledge including that of science and religion". (Singh 61)

The cult of Lord Jagannath is said to be a splendid synthesis of Tribalism, Buddhism, Jainism, Saivism, Saktism and Vaishnavism:

"The same log was interpreted as Sakti, Durga, Stambeswari or Subhadra under Sakta typology; as Siva or Linga or Balabhadra under Saiva typology and Sunya or Jagannath under Vaishnava typology". (Eschmann 99)

Some historians argue that while the triad was formed, the state was dominated by three important sects. Those were Saivism, Saktism and Vaishnavism. Hence the three idols of Subhadra, Balabhadra and Jagannath represented the three sects.

"During Hinduization, the same log was interpreted as Sakti, Durga, Stambeswari or Subhadra under Sakta typology; as Siva or Linga or Balabhadra under Saiva typology and as Sunya or Jagannath under Vaishnava typology." (Rath 160)

In this way the monotheistic conception of Daru Devata of Sabara culture became polytheistic and received appropriate appreciation in the course of time. Jagannath consciousness is a compendium of religion and ethics to achieve twin purposes of happiness in life and subsequent salvation too. It also stands for the ideals and approaches which modify mankind in humanistic manner. Moreover it trains an individual to gain oneness with the Supreme Being by establishing a delicate balance between the discipline of social order and the ultimate goal of life.

\section{Jaina origin of Lord Jagannath}

Apart from these three sectarian conceptions there are some 'otherisms' that have found rooms in the scope of Jagannath Consciousness. The practice of Jainism is to elevate the way in which the Individual Soul (Purusa) will identify itself with the ineffable Jagat-Purusa. This Jagat-Purusa is Jagannath, who is the idolatry manifestation of Cosmic Consciousness having a common appellation of the Jainas like Rishabhanatha and Parshvanatha, indicating a Purusa to be adored. The three figures of Lord Balabhadra, Goddess Subhadra and Lord Jagannath collectively symbolize the Jaina Trinity (triratna). They represent Samayak-janana (perfect knowledge), Samyak-caritra (the perfect conduct) and Samyak-dristi (the perfect vision). 


\section{Buddhist origin of Lord Jagannath}

Like Jainism, Buddhism also has significant contribution towards the emergence and expansion of Jagannath consciousness. The iconography of Lord Jagannath is unlike those of Gods of Hindu Pantheon. The prominently conspicuous circular eyes of Jagannath is said to symbolize Prajna (the supreme wisdom) and Sambodhi (perfect awakening). These are chiefly attributed to Buddha. The round eyes are evaluated to have resemblance with the Samyak Dristi (right view) of Buddhist ideology. General Cunningham, a Western Scholar advocates that the figures of Jagannath, Balabhadra and Subhadra are none but three modified representation of the Buddhist symbols of Triratnas such as Buddha, Dharma and Samgha. The Buddhist origin of the Jagannath figures provides evidence with the adoption of Buddha as the Brahminical Avatara (incarnation) in Hinduism. The aim of Buddhism is to obtain salvation with the worship of Triratnas. Again it is convinced that the Ratnavedi (jewelled pedestal) on which the Triad is installed is a replica of the Triratnas (Three-Jewels) of Buddhism. One can procure liberation from the illusory world by worshipping the Triad. The worship of physical halidom, the annual celebration of bathing ceremony (Snana Yatra) and the Gundicha Yatra are symptomatic of Buddhist practices. The well known historian W. W. Hunter has described the similarities between the Car Festival of Lord Jagannath and the tooth relic festival of Lord Buddha.

\section{Brahminical origin of Lord Jagannath}

The sects like Saivism, Saktism, Vaishnavism have greater contribution towards the healthy growth of Jagannath culture. According to Saivism, Lord Siva is the highest principle. He is the Lord of the universe having the power of generation, operation and destruction. Lord Jagannath in the Grand Temple is estimated as Vairava in accordance to the concept of Saivism. In the Utkal Khanda of Skandha Purana Lord Balabhadra is admired as Kalagni Rudra and Maharudra (world destroying aspects of Siva). Goddess Subhadra symbolizing supreme energy, is regarded as Durga - Maheswari. The concept of motherhood has been interpreted as Sakti in Jagannath culture. The worship of Vimala as Mahasaraswati, Mahalaksmi and Mohakali, is the witness of Saktism in Jagannath culture. Moreover, the cosmic power has three energetic aspects. These are Icchasakti (will power), Jnanasakti (wise power) and Kriyasakti (working power) that are represented through Balabhadra, Jagannath and Subhadra respectively.

In the ancient myths, and literary creations, Jagannath is adorned in various ways. Somewhere He is Nrisingha, some where He is Rama too. He is also revered as 'Gopijanaballava'. This Gopijanaballava brings us the childhood memory of Krishna especially His plays with Gopis (cowherd-women living in Braja Dham, in the Bhagavat). Hence the Vaishnavites believe that Jagannath is no other than Krishna. Scholars accept Him as the rallying point of precious sects. The followers of Sikh religion find a close connection with Jagannath, since Nanak, the founder of Sikh religion, was a passionate devotee of Lord Jagannath. It may be peculiar to estimate that the theology symbolized in the cross of Christ has certain correspondence with Jagannath Consciousness. Hence the cult of Jagannath is an amalgamation of various faiths and open bracket to embody humanitarian approaches, beyond caste, creed, religion or race.

Since antiquity Lord Jagannath has been an anxious agent accepting aura from various spiritual sphere and transmitting the tract of universal consciousness. He has been a forum for free exchange of philosophical, secular and intellectual curiosities and consequences of synthetic values too. Jagannath temple is a distinguished Hindu sanctum where the elements of different 
'isms' are reflected in its rituals. The ritualistic practices practiced in the Grand Temple have two major aspects. On the surface it seems to be a celebration including multi-ritual activities, performed by servitors. But its underlying significance encourages humanity to have a quest for Ultimate Truth, with the realization of Self through purification of physical entity and solemn entreaty. The rituals performed during celebrations like Navakalebara (New Embodiment) and Rathayrtra (Car Festival) also carry the same praiseworthy purpose.

\section{The New Embodiment: Navakalebara}

Navakalebara which is the assuming reincarnation of Lord Jagannath, is a reflexive ritual having referendum to the mortality of the Immortal in the discipline of Jagannath Consciousness. Although on the surface, we witness the transmigration of Brahma Padartha (the accepted soul substance) of four deities, from the relinquished old wooden bodies into the new Divine worshipables through restrictive spiritual metamorphosis, in reality, the ritual exemplifies the all-consuming capacity of Time in the mortal world. Etymologically the term 'Navakalebara' is derived from the combination of two words like 'naba' (new) and 'kalebara' (body). Hence Navakalebara refers to the new embodiment of wooden idols that are worshipped on the pedestal of spiritual sanctum sanctorum of the Grand Temple. It is not an annual celebration, it is restricted from eight to maximum nineteen years in which the month of Asadha (the $4^{\text {th }}$ month in Hindu almanac, normally occurs in June) becomes double in number. Such a month is called Joda Asadha which includes about sixty days and seems adequate for the extensive celebration of Navakalebara.

When Asadha doubles itself in a gap of 8 years and idols are not so ruined, the expensive process of Navakalebara is avoided. Instead, Shreeangphitaa (minor repairing) is executed for the deities. The Shreeangaphitaa procedure constitutes the removal of the seven layers of coating and clothing of the deities with the subsequent fresh application of silk clothing and packing of soft mixture composing sandal pastes, camphor and musk. These layers of clothing and packing make the idols afresh. This process of Shreeangaphitaa might be estimated as the discarding of old clothing by the embodied soul for new one. The naval centers of deities are neither opened nor the soul-substances touched. It is the complete embodiment of immortal soul substance. It is almost like the death of an old man, in which the Brahma Padartha (the mystic soul substance) is transplanted into a new-built-image, through a strenuous, stringent and esoteric process.

"The inter-relation of two original principles is the cause of the universe, Purusa is the conscious soul, self luminous but inactive, where as Prakriti is energy and is active. Purusa does nothing, it only reflects the action of Prakriti. Prakriti is mechanical but being reflected in Purusa it assumes the appearance of consciousness and thus the phenomena of creation, conservation, dissolution of birth and life and death, consciousness and unconsciousness, sense knowledge and intellectual knowledge and ignorance, action and inaction, happiness and sufferings - are all created". (Aurobindo 65)

Human bodies are finite in texture. The Indian philosophy believes that the soul which activates and uses the body, is infinite, eternal and indestructible. The soul substance does not accept birth nor death. It is also not a matter which comes into being once and goes away. Although it is not manifested outwardly, it is greater than all the manifestations. It cannot be evaluated by intellect. However it is mystically accepted as a spark of Divinity and eternal joy: 
"From joy people are born; for joy they live; in joy they melt at death. Death is an ecstasy, for it removes the burden of the body and frees the soul of all pain springing from body identification" (Paramahansa 219)

Death is the destination of all. No one has ever eluded it. Lord Jagannath during His mystic leela (sports) of the Navakalevara, has accepted the effect of Time, ethics of purity, ethos of death as well as eternity of soul. For Him death is the significant invention of life for its life editing ability.

\section{The Car Festival of Lord Jagannath}

Sri Jagannath Temple at Puri which is regarded as the crown jewel of Vaishnavite religion, witnesses 148 festivals in a year including 12 yatras (festivals), 28 upayatras (additional festivals) and 108 ritualistic festivals. The periodic celebration of festivals not only mitigates the melancholy of vulnerable life but also reflects cultural excellence and traditional vigour of a nation. The Car Festival of Lord Jagannath is one of the historically remarkable religious festivals celebrated enthusiastically in accordance with the scriptural prescriptions at Shreekshetra since antiquity. The Car Festival has now become a global festival. Innumerable pilgrims and visitors congregate at Puri to witness the famous Rathayatra (Chariot Journey Festival) of Jagannath and His associates in the month of Asadha (June-July) every year. According to spiritual scriptures, it is essential to celebrate festivals for the installed deities. When festivals are celebrated, the general public gets an opportunity to witness the occasion with certain entertainment to see their revered deities in the celebration.

"There may be devotees who are old, invalid and diseased and thus do not have the access to the shrine. All these people may be eager to have a darsan (sight) of the Lord. To satisfy such people festivals are observed." (Mishra 128)

Moreover, one of the religious scriptures named Harita Smurti (ch vi, sloka16) states that the celebration of festive rituals in the temples drives away the apprehensions of accidental fire, famine, flood and epidemics.

The celebration of the Car Festival (Rathayatra) during the rainy season has significance too. Some scholars advocate that the word 'barsa' (year) has been literally derived from the word 'barsa' or rain and this significant rainy season represents all the seasons in a year. Rain arrives as a harbinger of hilarity and brings vitality for mankind. Hence the Car Festival is observed in the rainy season. The rainy season has a symbolic and microcosmic value. The wind from the east during the season symbolizes spring. The showers including lighting flashes in the season produces autumnal effect. The pause of rain indicates fall winter and the alternative occurrence of heat and cold give the feeling of summer and winter. Hence, the rainy season includes all most all the elements of the natural seasons and presents itself as a complete organic whole. The inclusion of all the seasonal qualities in the rainy season makes it befitting for the performance of Car Festival which stands for cultural synthesis beyond religiosity.

The practices affixed to the Car Festival are immensely appealing. The ingrained beauty lies in paving an in-depth understanding of inner subjectivity. On the surface, the celebration seems supreme, when Lord Jagananth amid a huge congregation of devotees astride on His chariot called 'Nandighosha 'which literally means 'the Call of Bliss', and rolls towards the temple of Shree Gundicha. Lord Balabhadra ascends his chariot called 'Taladwaja' which means 'the glory of completeness'. Goddess Subhadra scales on her 'Darpadalana', which means 'elimination of vanity'. Although the Trinity with Lord Sudarshan (who settles in Darpadalan) participates in the 
grand Car Festival, Lord Jagannath is presupposed as the principality of institution. Hence the Car Festival is also entitled as 'Ghosa Yatra' after the Lord's chariot that is Nandighosa, which proclaims Ananda or eternal bliss. "Ananda refers to the state of infinite unalloyed pleasure which one experiences on attaining Brahmanhood" (Mohanty, A. 14). This is confirmed in the Bhagavad Gita (ch. 18, sloka 54): "Brahma-bhuta prasannatma na sochati na kankshyati - when one realizes his 'self, immediately he becomes joyful (prasannatma). The Chhandogya Upanishad (ch. vi, ii) also asserts Brahman to be the Ultimate Reality, and to realize Brahma is the secret of bliss. Brahma is beyond time, space. As per the Swetaswetara Upanishad (6.16 \& 6.5), "He is the maker of all, the knower of all, the self-caused, the knower, the author of time". He is to be seen beyond time. He is the beginning, the source of the causes which unite the soul with the body. This indemonstrable and invariable being can be realized as one only. While standing before the Lord (on the sanctum of Nandighosa), an intellectual investigates the metaphoric materials mingled with the infrastructure of the chariot and significance of Lord in it. The verses in the Katha Upanishad (1:3:3:4) provides certain clues for the understanding.

atmanam rathinam viddhi sariram rathameva tu

buddhim tu sarathim viddhi manh pragrahameva cha

indrayani hayarmahur visayam stenu gocharan

atmendriaya monoyuktam bhoktetyahur manasinah.

(Body is the chariot, soul is the charioteer. Senses are horses. Mind is the bridle. All the sensory objects constitute the root for the horses. The co-ordination among the soul, senses and mind will bring supernatural bliss). Brahman being the macrocosmic consciousness, has created the world. He also resides in each living being as the essence and the inner self.

esa sarvesu bhutesu gudhatma na prakasate drusyate twagraya buddhaya sukhmaya sukhmadarsivih (The Katha Upanishad, 1.3.12)

(The Self does not-shine on surface, though it is hidden in all beings. The subtle seers having sharp intelligence can see it only).

As Mohanty explains,

"Hindu cosmogony, by and large, rests on three fundamental visions, namely 'one' evolves into 'many', the 'many' evolve into 'one' and the beginning and end of the evolution is one and the same. Evolution is a passage from 'unity' to 'unity', in and through diversity. The perceived diversities are phenomenal. At the core, there is one selfsame consciousness. That, which is 'one' appears as 'many', just as air which is formless, assumes different forms, depending on the nature of the bubble in which it resides." (Mohanty, A. 21)

In the Katha Upanishad, we find the mystery

bayujryathaiko bhabanam prabisto

rupam rupam pratirupo babhuba

akastatha sarbobhutantaratma

rupam rupam pratirupo bahischa. (The Katha Upanishad, II, 2.10)

(As air accepts different shapes according to the container it enters, the 'Self [Brahman] within all living being in varied in and out of all, God manifests Himself as the soul in all the animates.) 
The body may be taken as a chariot and Lord Jagannath appears as Vamana (miniature form) in it.

"He is the eye of all eyes, the nose of all noses, the ear of all ears.- He is the Lord of everchanging cosmos. The Lord of the universe or jagat, is Jagannath. In the body chariot, realization and the darsan of the soul as Vamana - Lord Jagannath will lead to liberation, to freedom from the cycle of birth and death, and to freedom from all forms of sorrow. Without this realization, this human life chariot will be driven astray by the extroverted sense horses. The mind without a bridle will surely be afflicted with sorrows, sufferings, adversities and despondency." (Prajnanananda 172)

As human body is a precious channel to expedite the God-ward Journey, the call of Jagannath Consciousness encourages an aspiring devotee to make his heart a hermitage of God.

\section{Conclusion}

As discussed, Lord Jagannath has been the encouraging and inspiring divine force behind the socio-cultural life of people in Odisha since time immemorial. When the contemporary world is vivisected by the vagaries of divergence and vestiges of structural and utilitarian acrimonies ingrained in the religiosities, Jagannath consciousness seems to be a beacon of hope to beget a sense of universalism and cosmopolitanism through its ethical values. In the context of the contemporary world, which is tormented by terrorism, regional disputes, religious bigotry, disintegration of the traditional society and the growth of materialistic outlook, the cosmic consciousness of Lord Jagannath is the doctrine to establish a substantive and sustainable system of humanitarian values and universality.

\section{Works Cited}

Aurobindo, S. (1972). Sri Aurobindo Birth Centenary Library. Pondicherry: Sri Aurobindo Ashram, Vol.13.

Eschmann, A. (1978). "The Vaishnava Typology of Hinduization and the Origin of Jagannath", The Cult of Jagannath and the Regional Tradition of Orissa. New Delhi: Manohar Publications.

Parmananda, Swami (2004). "Katha Upanishad". The Upanishads. 1st World Publishing.

Mishra, K.C. (1971). The Cult of Jagannath. Calcutta: Firma K. L. Mukhopadhyay.

Mohanty, Aditya Kumar. (2006). Hinduism, Comparative Religion, Concepts and Issues. Bhubaneswar: P.G. Department of Philosophy, Utkal University.

Prajnanananda Paramahansa. (2015). Lord Jagannath Through the Eyes of A Yogi. Austria: Prajna Publication.

Rath, D.P. (1995). The Concept of Jagannath and Jagannath Culture - A Philosophical Analysis. Ph. D. Thesis in Philosophy submitted to Utkal University.

Samantaray, S. (2013). 'Demystifying Mysticism: A Comparative Study of the Poetry of William Blake and Rabindranath Tagore'. 3L: Language, Linguistics, Literature The Southeast Asian Journal of English Language Studies. Vol. 19, No 2, p. 41-51.

Singh, T.D. (2013).Consciousness. Kolkata: Bhaktivedanta Institute. 